\title{
Immune checkpoint inhibitor-related myositis and myocarditis in patients with cancer
}

Neurology ${ }^{\circledR}$ 2019;93:280. doi:10.1212/WNL.0000000000007380

In the article "Immune checkpoint inhibitor-related myositis and myocarditis in patients with cancer" by Touat et al., ${ }^{1}$ there were several errors published in the online ahead-of-print version on August 8, 2018. The corrected article was posted online on September 4, 2018.

- The legend for figure $1 \mathrm{~B}$ should have included "Arrowheads indicate patients with both myocarditis and myositis" and should also have specified "myositis associated with immune checkpoint inhibitors" rather than "myositis induced by treatment with immune checkpoint inhibitors."

- In figure $2 \mathrm{G}$, the scalebar is $20 \mu \mathrm{m}$, rather than $50 \mu \mathrm{m}$, as originally published ahead-ofprint.

- The table 1 legend should have noted "aperformance status at the time of ICI initiation" and reordered the following notes accordingly.

- In the Glossary, irMyositis should have been defined as "myositis associated with immune checkpoint inhibitors" rather than "myositis induced by immune checkpoint inhibitors," as originally published. Further, PD-L1 and PD-L2 should have been defined as "programmed cell death 1 ligand 1" and "programmed cell death 1 ligand 2," and PD-1 should have been defined as "programmed cell death protein 1." In the ahead-of-print version, these 3 acronyms were incorrectly expanded as "programmed death-ligand 1," "programmed death-ligand 2," and "programmed death-1 receptor," respectively. Lastly, CTLA-4 should have been defined as "cytotoxic T-lymphocyte associated protein 4" rather than "...T lymphocyte-associated antigen 4."

- In the affiliations list, Dr. Timothée Lenglet was incorrectly listed with Service de Neurologie Raymond Escourolle rather than the Department de Neurophysiologie Clinique at Hôpitaux Universitaires La Pitié Salpêtrière-Charles Foix.

- In the author contributions section, Dr. Pauline Laly should have been listed as assisting with acquisition and interpretation of data, and critical revision of manuscript for intellectual content.

- In the Disclosure section, Dr. Touat's statement should have read as follows (with changes italicized): "M. Touat is a consultant/advisory board member for Agios Pharmaceutical and Taiho Oncology and reports travel grants from Merck Sharp and Dohme, outside the submitted work."

The publisher regrets these errors.

\section{Reference}

1. Touat M, Maisonobe T, Knauss S, et al. Immune checkpoint inhibitor-related myositis and myocarditis in patients with cancer. Neurology 2018;91:e985-e994. 


\section{Neurology}

\section{Immune checkpoint inhibitor-related myositis and myocarditis in patients with cancer Neurology 2019;93;280 \\ DOI 10.1212/WNL.0000000000007380}

This information is current as of August 5, 2019

Updated Information \&
Services

References

Permissions \& Licensing

Reprints including high resolution figures, can be found at: http://n.neurology.org/content/93/6/280.full

This article cites 1 articles, 1 of which you can access for free at: http://n.neurology.org/content/93/6/280.full\#ref-list-1

Information about reproducing this article in parts (figures,tables) or in its entirety can be found online at:

http://www.neurology.org/about/about_the_journal\#permissions

Information about ordering reprints can be found online:

http://n.neurology.org/subscribers/advertise

Neurology ${ }^{\circledR}$ is the official journal of the American Academy of Neurology. Published continuously since 1951, it is now a weekly with 48 issues per year. Copyright () 2019 American Academy of Neurology. All rights reserved. Print ISSN: 0028-3878. Online ISSN: 1526-632X.

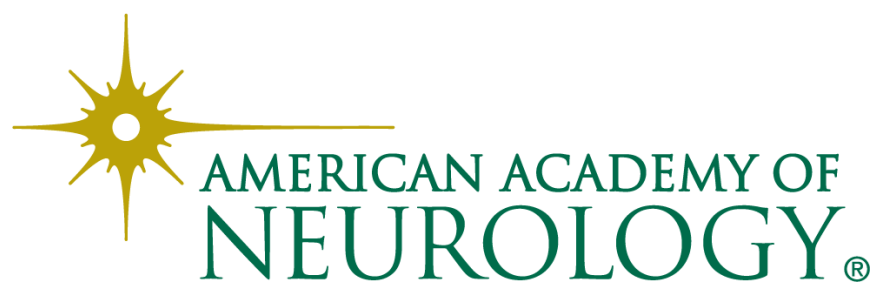

